\title{
Patent Ductus Arteriosus Ligation Alters Pulmonary Gene Expression in Preterm Baboons
}

\author{
NAHID WALEH, DONALD C. MCCURNIN, BRADLEY A. YODER, PHILIP W. SHAUL, AND RONALD I. CLYMAN
}

\begin{abstract}
Pharmaceutical Discovery Division [N.W.], SRI International, Menlo Park, California 94025; Department of Pediatrics [D.C.M., B.A.Y.], University of Texas, Health Science Center, San Antonio, Texas 78229; Southwest Foundation for Biomedical Research [D.C.M., B.A.Y.], San Antonio, Texas 78227; Department of Pediatrics [P.W.S.], University of Texas Southwestern Medical Center, Dallas, Texas 75235; Cardiovascular Research Institute and Department of Pediatrics [R.I.C.], University of California San Francisco, San Francisco,
\end{abstract} California 94143

\begin{abstract}
Ibuprofen-induced ductus closure improves pulmonary mechanics and increases alveolar surface area in premature baboons compared with baboons with a persistent patent ductus arteriosus (PDA). Ibuprofen-treatment has no effect on the expression of genes that regulate pulmonary inflammation but does increase the expression of alpha-ENaC (the transepithelial sodium channel that is critical for alveolar water clearance). Although ligation eliminates the PDA, it does not improve pulmonary mechanics or increase alveolar surface area. We used preterm baboons (delivered at $67 \%$ of term gestation and ventilated for $14 \mathrm{~d}$ ) to study whether the lack of beneficial effects, after PDA ligation, might be due to alterations in pulmonary gene expression. We found no differences in ventilation or oxygenation indices between animals that were ligated $(n=7)$ on day of life 6 and those that had a persistent PDA $(n=12)$ during the entire $14 \mathrm{~d}$ study. In contrast with no intervention, PDA ligation produced a significant increase in the expression of genes involved with pulmonary inflammation $(C O X-2, T N F-\alpha$, and $C D 14)$ and a significant decrease in alpha-ENaC sodium channel expression. We speculate that these changes may decrease the rate of alveolar fluid clearance and contribute to the lack of improvement in pulmonary mechanics after PDA ligation. (Pediatr Res 69: 212-216, 2011)
\end{abstract}

A persistent left-to-right shunt through a patent ductus arteriosus (PDA) increases the rate of hydrostatic fluid filtration into the lung's interstitium (1), impairs pulmonary mechanics (2-7), prolongs the need for mechanical ventilation (8), and alters alveolar surface area (9). Although pharmacologic closure of the PDA, with indomethacin or ibuprofen, prevents the deterioration of pulmonary function and alveolar development $(2,7,9,10)$, there is little information to guide neonatologists in what to do when the PDA fails to close after pharmacologic treatment. Two small randomized-controlled trials, performed almost $30 \mathrm{y}$ ago, compared the effects of ligating the PDA (when signs of congestive failure develop) with allowing the PDA to persist indefinitely $(8,11)$. Both studies found that surgical closure of the PDA decreased the need for prolonged ventilatory support $(8,11)$. Whether these findings are still applicable in the

Received July 6, 2010; accepted October 12, 2010.

Correspondence: Ronald I. Clyman, M.D., Cardiovascular Research Institute and Department of Pediatrics, University of California, San Francisco, UCSF Box 0544, HSW 1408, 513 Parnassus Avenue, San Francisco, CA 94143-0544; e-mail: clymanr@peds.ucsf.edu

Supported by NIH Grants HL46691, HL56061, HL52636 BPD Resource Center, and P51RR13986 Primate Center facility support from U.S. Public Health Service and by a gift from the Jamie and Bobby Gates Foundation. setting of modern neonatal treatment has become a matter of controversy among neonatologists (12).

Although ductus ligation eliminates the PDA, it does not seem to have the same beneficial effects on lung development as pharmacologic closure $(10,13-17)$. In recent years, there has been concern that PDA ligation may actually contribute to the pulmonary morbidity it is trying to prevent $(10,15-21)$. Population-based observational studies have found that early surgical ligation is an independent risk factor for the development of bronchopulmonary dysplasia (BPD) and other neonatal morbidities $(15,16)$. In addition, several randomized- and cohortcontrolled trials suggest that early ductus ligation may contribute directly to the development of BPD and prolonged ventilatory requirements $(17,22,23)$.

The premature baboon, delivered at $125 \mathrm{~d}$ gestation (67\% of gestation, term $=185 \mathrm{~d}$ ), has been used to explore the causes of BPD. The premature baboon has a similar neonatal course as the premature human delivered between 26 and 27 wk of gestation (24): they both develop respiratory distress and fail to close their PDA after birth. Despite surfactant treatment, total parenteral nutrition, low tidal volume ventilation, and low supplemental oxygen administration during the first 2 wk after delivery, premature baboons develop pulmonary histopathologic changes that are similar to those described in premature human infants with BPD $(25,26)$.

When compared with premature baboons with a persistent PDA, baboons that are treated with ibuprofen to close their PDA have improved pulmonary mechanics and increased alveolar surface area (9). Ibuprofen treatment has no effect on the expression of genes that regulate pulmonary inflammation and remodeling but does increase the expression of alpha subunit containing transepithelial sodium channels (alpha-ENaC, which are responsible for lung water clearance; 9).

In contrast, premature baboons that have their PDA closed by surgical ligation have no improvement in pulmonary mechanics or alveolar growth compared with untreated controls $(13,27)$. Because proinflammatory cytokines/chemokines and mediators of parenchymal and vascular remodeling have been associated with the development of BPD $(9,28-35)$, we examined whether

Abbreviations: alpha-ENaC, alpha subunit containing transepithelial sodium channel; BPD, bronchopulmonary dysplasia 
the lack of beneficial effects, after PDA ligation, might be due to alterations in pulmonary gene expression after the surgery. We found that, in contrast to no intervention (leaving the ductus patent), surgical closure of the PDA produced a significant increase in the expression of genes involved with pulmonary inflammation and remodeling and a significant decrease in the expression of the alpha-ENaC epithelial sodium channel gene.

\section{METHODS}

Studies were reviewed and approved by the Institutional Animal Care and Use Committee at the Southwest Foundation for Biomedical Research Primate Center (SWBRPC) in San Antonio, TX, and were performed at SWBRPC. Necropsy lung samples were obtained from animals that had previously participated in a controlled trial of PDA ligation (27). A complete description of the animal care and surgical procedures have been published elsewhere (25-27). Briefly, timed pregnant baboon (Papio papio) dams were delivered at $125 \pm 1 \mathrm{~d}$ gestation (full term $=185 \mathrm{~d}$ ) and their newborns were mechanically ventilated for $14 \mathrm{~d}$. The dams did not receive antenatal glucocorticoids. At birth, the infants were weighed, sedated, intubated, and given surfactant (Survanta; courtesy of Ross Laboratories, Columbus, $\mathrm{OH}$ ) before initiation of ventilator support (InfantStar; Infrasonics, San Diego, CA). Ventilator adjustments were made based on chest radiograph, clinical examination, arterial blood gas measurement, and tidal volume measurement (26). Target goals for $\mathrm{PaO}_{2}$ were 55 to $70 \mathrm{~mm} \mathrm{Hg}$, for $\mathrm{PaCO}_{2}$ were 45 to $55 \mathrm{~mm} \mathrm{Hg}$, and for tidal volume were 4 to $6 \mathrm{~mL} / \mathrm{kg}$. Nutritional, fluid, transfusion, antibiotic, and blood pressure management have been previously described (26). None of the animals received postnatal steroids.

Animals were randomized before delivery to either ductal ligation (LIGATION, $n=7$ ) at $6 \mathrm{~d}$ after birth or no intervention (CONTROL, $n=12$ ). This time point was chosen because the animals are relatively stable from a cardiopulmonary standpoint and because previous experience has shown that the animals do not tolerate the surgery before day of life 5-6. Animals in the LIGATION group underwent ductus ligation, using standard surgical techniques, after induction of anesthesia with ketamine $(10 \mathrm{mg} / \mathrm{kg})$ and fentanyl $(20 \mu \mathrm{g} / \mathrm{kg})$ and muscle relaxation with pavulon $(0.1 \mathrm{mg} / \mathrm{kg})$. Animals in the CONTROL group did not receive anesthesia or sham surgery because our intention was to mimic the clinical care of human newborns.

The newborns were studied for the first $14 \mathrm{~d}$ after birth because beyond $14 \mathrm{~d}$, there is a high likelihood that the animals would develop septicemia and/or pneumonia (25). Because sepsis plays a significant role in the development of chronic lung disease in the preterm, the presence of septicemia/pneumonia in the animals would significantly alter our ability to detect differences due to other interventions. The x-rays were obtained daily, and surveillance cultures were obtained while the animals were alive; histologic examinations were performed at necropsy. None of the animals in the CONTROL or LIGATION groups developed septicemia or pneumonia during the study period.

Pulmonary function testing was performed using the VitalTrends plethysmograph system (VT1000; Vitaltrends Technology, New York, NY). The reproducibility and sensitivity of this system have been described previously (26). Compliance measurements were of the respiratory system as a whole and were corrected for body weight. Oxygenation index [mean airway pressure $(\mathrm{cm}$. $\left.\mathrm{H}_{2} \mathrm{O}\right) \times \mathrm{FiO}_{2} \times 100 / \mathrm{PaO}_{2}$; where $\mathrm{FiO}_{2}$ represents fraction of inspired oxygen[and ventilation index (peak inspiratory pressure $\times$ ventilator rate $\times \mathrm{PaCO}_{2} / 1000$ ) were calculated at the same times.

A complete echocardiographic examination, including assessment of ductal patency, was performed daily using an $8-\mathrm{mHz}$ transducer interfaced with a Biosound AU3 echocardiographic system (Genoa, Italy) (36,37). The findings related to the animals' clinical course, cardiovascular performance, and hemodynamic and pulmonary measurements have been published in detail elsewhere $(13,27)$.

Preparation of lung total RNA, reverse transcription and quantitative $\boldsymbol{P C R}$. At necropsy (d 14), tissue from the right middle lobe (contralateral to the side of the ductus surgery) was immediately frozen in liquid nitrogen for RNA isolation, as previously described (38). TaqMan Universal PCR master mix of PE Applied Biosystems (Foster City, CA) was used to quantify the expression of the genes of interest. Taqman probes were designed using the Primer Express program and labeled with fluorophores FAM (6-caboxy-fluorescein) and TAMRA (6 carboxy-tetramethyl-rhodamine) as reporter and quencher dyes, respectively. An ABI PRISM 7500 Sequence detection system was used to determine the cycle threshold (CT). Reactions were carried out in triplicates. Data were analyzed using the Sequence Detector version 1.6.3 program. Malate dehydrogenase (MDH) was used as an internal control to normalize the data (39).

Control fetuses. Lung tissue (right middle lobe) was also obtained from $140 \mathrm{~d}$ gestation premature fetuses $(n=11)$ that had remained in utero for the equivalent 14-d newborn experimental period (from 125 to $140 \mathrm{~d}$ ). Fetuses were delivered by cesarean section and killed before breathing.

Statistics. Data are presented as mean \pm SD. Our sample size was limited both by the expense of the model and our attempt to limit the use of this precious animal resource. Between-group differences were compared by unpaired $t$ test or the Mann-Whitney rank-sum test where appropriate. Statistical results were generated using Statview (SAS Institute, San Francisco) software.

\section{RESULTS}

Nineteen newborn animals $(\mathrm{CONTROL}=12$; LIGATION $=$ 7) were ventilated for $14 \mathrm{~d}$. All animals had a patent ductus on $\mathrm{d}$ 6 (the day of planned ductus ligation). There were no differences between the two groups in birth weight (CONTROL $=402 \pm$ $44 \mathrm{~g}$; LIGATION $=418 \pm 29 \mathrm{~g})$, sex $(\%$ male: CONTROL $=$ $58 \%$; LIGATION $=71 \%)$, gestation $(\mathrm{CONTROL}=125 \pm 1 \mathrm{~d}$; LIGATION $=125 \pm 1 \mathrm{~d}$ ), or in any of the measured parameters before the time of planned ductus ligation (d 6; see later).

Before ductus ligation, both groups had similar systemic blood pressures and similar degrees of left-to-right PDA shunt (as reflected by the pulmonary-to-systemic blood flow ratios (13)). The ductus in the CONTROL group stayed open throughout the 14-d experiment; the average pulmonary-to-systemic blood flow ratio (Qp/Qs) for the CONTROL group from d 7 through 13 was $1.9 \pm 0.7$. In contrast, after the ligation, the $\mathrm{Qp} / \mathrm{Qs}$ ratio for the LIGATION group was $1.0 \pm 0.1(p<0.05)$. Animals in the LIGATION group had significantly higher mean systemic blood pressures at all times after the ligation (average mean blood pressure from d 7 through 13 was $38 \pm 4 \mathrm{~mm} \mathrm{Hg} \mathrm{CONTROL}$ and $42 \pm 4 \mathrm{~mm}$ Hg LIGATION). There were no differences in the fluid intake and urine output between the two groups nor were there differences between the two groups in base deficit, serum bicarbonate, or need for dopamine/dobutamine administration during the $14 \mathrm{~d}$ treatment course (13). Similarly, there were no differences in ventilation index, dynamic compliance, or oxygenation index between the two groups, during both the preoperative and postoperative periods (13).

Premature birth and mechanical ventilation altered gene expression in the newborn lung. Compared with nonventilated premature fetuses, the CONTROL premature newborns had altered mRNA expression of genes involved with inflammation, epithelial water reabsorption, surfactant production, lung remodeling, and vascular growth and contractility (Table 1). Several genes increased their expression after premature birth $(C D 14$, cyclooxygenase 2, TNF- $\alpha$, alpha-ENaC epithelial sodium chan$n e l$, and surfactant protein B), whereas others (IL-6 and most of the genes involved with vascular growth and lung remodeling) had decreased expression after preterm birth (Table 1).

At the time of necropsy, $8 \mathrm{~d}$ after the ductus ligation, gene expression in the right middle lobe of the animals that underwent PDA ligation was significantly altered compared with the right middle lobe of unoperated newborn CONTROLS. There was a significant increase in the expression of genes involved with inflammation (CD14, cyclooxygenase 2, and TNF- $\alpha$ ) and a decrease in the expression of the gene involved with lung water reabsorption (alpha-ENaC) in the LIGATION group (Table 2).

\section{DISCUSSION}

BPD is characterized primarily by impaired alveolar and vascular growth $(25,40)$. After ibuprofen-induced ductus clo- 
Table 1. Real-time PCR measurements of RNA expressed by preterm fetal and preterm neonatal lung (right middle lobe)

\begin{tabular}{|c|c|c|c|c|c|}
\hline \multirow[b]{2}{*}{ Gene } & \multicolumn{2}{|c|}{$\begin{array}{l}\text { Preterm fetus }(140 \mathrm{~d} \\
\text { gestation) } \Delta \mathrm{CT} \\
(\mathrm{MDH}-\text { gene })\end{array}$} & \multicolumn{2}{|c|}{$\begin{array}{l}\text { Preterm newborn }(14 \mathrm{~d} \\
\text { no ligation) } \Delta \mathrm{CT} \\
(\mathrm{MDH}-\text { gene })\end{array}$} & \multirow{2}{*}{$\begin{array}{c}\text { Comparison Preterm newborn } \\
v s \text { preterm fetus } p<0.05\end{array}$} \\
\hline & Mean & $\mathrm{SD}$ & Mean & SD & \\
\hline \multicolumn{6}{|l|}{ Inflammation } \\
\hline$C D 14$ & -3.113 & 0.264 & -2.358 & 0.427 & - \\
\hline$C O X-2$ & -6.742 & 0.406 & -5.429 & 0.551 & - \\
\hline$I L-6$ & -5.042 & 0.499 & -6.981 & 1.002 & $=$ \\
\hline$I L-8$ & -4.190 & 0.614 & -4.352 & 0.698 & - \\
\hline$T N F-\alpha$ & -9.899 & 0.429 & -7.983 & 0.795 & - \\
\hline \multicolumn{6}{|l|}{ Epithelial water reabsorption } \\
\hline Alpha-ENaC & -3.421 & 0.311 & -2.161 & 0.533 & 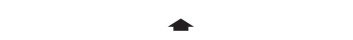 \\
\hline \multicolumn{6}{|c|}{ Vascular growth and contractility } \\
\hline ANGPT2/angiopoietin-2 & -5.184 & 0.594 & -6.987 & 0.497 & - \\
\hline eNOS & -4.683 & 0.261 & -6.183 & 0.450 & - \\
\hline ETA receptor & 0.322 & 0.162 & -0.756 & 0.385 & $=$ \\
\hline CDH5/VE-cadherin & 0.004 & 0.140 & -0.748 & 0.367 & $=$ \\
\hline$V E G F$ & 1.243 & 0.159 & -0.370 & 0.376 & - \\
\hline VEGFR1/FLT-1 & -1.070 & 0.281 & -2.810 & 0.415 & - \\
\hline$V E G F R 2 / K D R$ & 0.271 & 0.251 & -0.917 & 0.428 & - \\
\hline$H A S-2$ & -6.388 & 1.082 & -7.857 & 1.703 & $=$ \\
\hline HIF2 alpha & 2.324 & 0.255 & 1.920 & 0.412 & - \\
\hline$M M P-9$ & -3.180 & 0.725 & -4.461 & 0.579 & - \\
\hline RHAMM & -5.886 & 0.331 & -5.147 & 0.558 & $=$ \\
\hline TGFbetal & -2.580 & 0.224 & -2.760 & 0.450 & - \\
\hline TGFbeta 3 & -1.847 & 0.256 & -2.707 & 0.324 & - \\
\hline \multicolumn{6}{|l|}{ Surfactant } \\
\hline$S P-B$ & 4.291 & 0.179 & 5.865 & 0.372 & - \\
\hline
\end{tabular}

Right middle lobe lung tissue was obtained from preterm newborn baboons that were delivered at $125 \pm 1 \mathrm{~d}$ gestation (full term $=185 \mathrm{~d}$ ) and mechanically ventilated for $14 \mathrm{~d}$ (preterm newborn, 14-d-old, no ligation group). Lung tissue was also obtained from preterm $140 \mathrm{~d}$ gestation fetuses (preterm fetus, $140 \mathrm{~d}$ gestation) that had remained in utero for the equivalent 14-d-old newborn experimental period (from 125 to $140 \mathrm{~d}$ ).

$\Delta \mathrm{CT}$ represents the difference in cycle threshold (CT) between the expression of the housekeeping gene malate dehydrogenase (MDH) and the gene of interest. Each unit of $\Delta \mathrm{CT}$ represents a 2-fold change in a gene's mRNA. The more negative the $\Delta \mathrm{CT}$, the fewer the number of starting copies of a gene (mRNA). Number of separate animals used: preterm fetus ( $140 \mathrm{~d}$ gestation; no antenatal betamethasone; $n=11)$ and preterm newborn (14-d-old/no ligation; $n=12)$. Preterm newborn $v s$ preterm fetus: right middle lobes from 14-d-old newborns (whose PDA was not ligated) were compared with right middle lobes from fetuses that remained in utero until $140 \mathrm{~d}$ gestation. $p<0.05$, newborn right middle lobe $\Delta \mathrm{CT}$ was significantly greater than fetal right middle lobe $\Delta \mathrm{CT}$; $-p<0.05$, $\Delta \mathrm{CT}$ was significantly less; $-p>0.05$, was not significantly different.

sure, premature baboons have improved pulmonary mechanics and increased alveolar surface area compared with premature baboons with a persistent PDA (9). It has been hypothesized that the decreased need for mechanical ventilation may contribute to the improved alveolarization that occurs after pharmacologic PDA closure $(28,41)$. In contrast, baboons that have their PDA closed by surgical ligation show no signs of improved pulmonary mechanics (see Results) or increased alveolar growth $(13,27)$. We hypothesized that the trauma of PDA surgery may have obscured the potential benefits of PDA closure on postnatal lung mechanics and development.

Alterations in the production of proinflammatory cytokines/ chemokines and mediators of parenchymal and vascular remodeling have been associated with the development of BPD. Premature delivery and mechanical ventilation are known to alter the expression of inflammatory mediators in both human and baboon lungs $(9,28-35)$. Compared with nonventilated fetuses, we found that premature newborn baboons have both decreased expression of genes involved with new vessel growth and lung remodeling and increased expression of genes involved with pulmonary inflammation (Table 1). Similar changes have been observed previously in other studies using premature newborn baboons $(9,42-44)$. These findings are consistent with other studies that suggest that disruption of angiogenesis may play a significant role in impaired alveolarization (45).

The novel findings in the current study relate to the effects of surgical PDA ligation on pulmonary gene expression. We found that, in contrast to no intervention (leaving the ductus patent), surgical PDA closure increased the expression of several inflammatory mediators $(C O X-2, T N F-\alpha$, and cells expressing $C D 14)$ and decreased the expression of several genes involved in angiogenesis (angiopoietin-2 and TGF beta 3) (46). Surgical PDA closure also decreased the expression of pulmonary alpha-ENaC containing channels (which are involved in transepithelial sodium transport). It should be noted that the changes we observed were in lung tissue taken from the side opposite to the ligation, more than a week after the surgery.

Clearance of fluid from alveolar airspaces requires the presence of amiloride-sensitive alpha-ENaC channels (47). In contrast with full-term newborn baboons, preterm baboons have diminished expression of alpha-ENaC channels and slow rates of fluid clearance from their lungs (9). The improvement in pulmonary mechanics that follows pharmacologic closure of the PDA (with ibuprofen or indomethacin) is associated with increased pulmonary expression of the alpha-ENaC channels and increased lung water clearance (9). The effects of ibuprofen and indometh- 
Table 2. Real-time PCR measurements of RNA expressed by right middle lobe from LIGATION and CONTROL preterm newborn animals

\begin{tabular}{|c|c|c|c|c|c|}
\hline \multirow[b]{2}{*}{ Gene } & \multicolumn{2}{|c|}{$\begin{array}{c}\text { Newborn } 14 \text { d no ligation } \\
\Delta \mathrm{CT}(\mathrm{MDH}-\text { gene })\end{array}$} & \multicolumn{2}{|c|}{$\begin{array}{l}\text { Newborn } 14 \mathrm{~d} \text { ligation } \\
\Delta \mathrm{CT}(\mathrm{MDH}-\text { gene })\end{array}$} & \multirow{2}{*}{$\begin{array}{c}\text { Comparison } \\
\text { Newborn-ligation } v s \\
\text { newborn-no ligation } \\
\quad p<0.05\end{array}$} \\
\hline & Mean & SD & Mean & SD & \\
\hline \multicolumn{6}{|l|}{ Inflammation } \\
\hline$C D 14$ & -2.358 & 0.427 & -1.776 & 0.176 & - \\
\hline$C O X-2$ & -5.429 & 0.551 & -4.561 & 0.474 & - \\
\hline$I L-6$ & -6.981 & 1.002 & -6.376 & 0.599 & - \\
\hline$I L-8$ & -4.352 & 0.698 & -4.298 & 0.262 & - \\
\hline$T N F-\alpha$ & -7.983 & 0.795 & -7.457 & 0.593 & - \\
\hline \multicolumn{6}{|l|}{ Epithelial water reabsorption } \\
\hline Alpha-ENaC & -2.161 & 0.533 & -2.533 & 0.079 & $=$ \\
\hline \multicolumn{6}{|c|}{ Vascular growth and contractility } \\
\hline ANGPT2/angiopoietin-2 & -6.987 & 0.497 & -7.465 & 0.362 & $=$ \\
\hline eNOS & -6.183 & 0.450 & -6.173 & 0.261 & - \\
\hline ETA receptor & -0.756 & 0.385 & -0.876 & 0.156 & - \\
\hline CDH5/VE-cadherin & -0.748 & 0.367 & -0.933 & 0.154 & - \\
\hline$V E G F$ & -0.370 & 0.376 & -0.607 & 0.295 & - \\
\hline VEGFR1/FLT-1 & -2.810 & 0.415 & -3.113 & 0.253 & - \\
\hline$V E G F R 2 / K D R$ & -0.917 & 0.428 & -0.929 & 0.250 & - \\
\hline \multicolumn{6}{|l|}{ Remodeling } \\
\hline$H A S-2$ & -7.857 & 1.703 & -7.109 & 1.430 & - \\
\hline HIF2 alpha & 1.920 & 0.412 & 2.092 & 0.196 & - \\
\hline$M M P-9$ & -4.461 & 0.579 & -4.105 & 0.336 & - \\
\hline RHAMM & -5.147 & 0.558 & -5.289 & 0.391 & - \\
\hline TGFbetal & -2.760 & 0.450 & -2.996 & 0.072 & - \\
\hline TGFbeta 3 & -2.707 & 0.324 & -3.125 & 0.374 & - \\
\hline \multicolumn{6}{|l|}{ Surfactant } \\
\hline$S P-B$ & 5.865 & 0.372 & 5.895 & 0.210 & - \\
\hline
\end{tabular}

See legend to Table 1 for explanation of $\Delta \mathrm{CT}$. The more negative the $\Delta \mathrm{CT}$, the fewer the number of starting copies of a gene (mRNA). Number of separate animals used: CONTROL (newborn 14-d-old no ligation; $n=12$ ); LIGATION (newborn $14-\mathrm{d}$-old ligation; $n=7$ ). Newborn ligation $v s$ newborn no ligation: right middle lobes from 14-d-old newborns (whose PDA were ligated) were compared with right middle lobes from newborns (whose PDA were not ligated). - $p<0.05$, LIGATION right middle lobe $\Delta \mathrm{CT}$ was significantly greater than CONTROL right middle lobe $\Delta \mathrm{CT} ;-p<0.05, \Delta \mathrm{CT}$ was significantly less; $-p>0.05$, was not significantly different.

acin on alpha-ENaC expression seem to be because of their inhibition of cyclooxygenase activity, rather than their effect on ductus closure (9). We speculate that the increased expression of cyclooxygenase 2, which follows PDA ligation (Table 2), may account for the decreased expression of alpha-ENaC in the lungs of ligated animals (Table 2). We also speculate that reduced expression of pulmonary alpha-ENaC channels may decrease the rate of fluid movement out of the alveolar compartment and contribute to the lack of improvement in pulmonary mechanics after surgical PDA closure. Unfortunately, the lungs of the ligated animals were not harvested at the time of necropsy in a manner that would allow us to examine them for changes in lung water content or distribution.

Our study has several other limitations. We were limited in the number of control groups we could study because of the expense and need to restrict the use of this precious animal model. Having a control group that received a thoracotomy, without a PDA ligation, could have helped to identify which aspect of the surgery leads to altered pulmonary gene expression. Similarly, because surgical closure in the NICU often follows failure of medical treatment, having a control group that received a thoracotomy after treatment with indomethacin, could have identified whether the use of indomethacin before ligation would ameliorate the "detrimental" effects of the surgical ligation in this animal model.

In conclusion, our findings are consistent with the limited amount of data available from clinical studies. There is little evidence to suggest that surgical ductus closure prevents the evolution of BPD $(15-17,22,23)$. We speculate that the persistent alterations in inflammatory mediators and alpha-ENaC channels (that we observed with ligation) may account for the lack of improvement in pulmonary mechanics and BPD (13) after surgical closure.

In addition to the changes we observed, ductus ligation has also been associated with several other significant morbidities: thoracotomy, postoperative myocardial dysfunction (48), hypotension (18), pneumothorax, chylothorax, infection, and vocal cord paralysis $(10,18)$. In sum, ductus ligation, while eliminating one potential cause for neonatal morbidity, may introduce another set of problems. We suggest that both the desired and achievable goals of ductus ligation be carefully evaluated before committing infants to early or routine surgical closure.

Acknowledgments. We thank the personnel at the BPD Resource Centre for their help in the care of the animals and the University of Texas Health Science Center San Antonio pathology staff who performed the necropsies and obtained the tissues. We also thank Vickie Winter, who has skillfully managed to categorize and keep track of all the tissue samples and animal data over the years and Dr. Jackie Coalson, who provided invaluable leadership, guidance, and scientific oversight for the BPD Resource Center and with whom we have had many thought-provoking discussions. 


\section{REFERENCES}

1. Alpan G, Scheerer R, Bland RD, Clyman R 1991 Patent ductus arteriosus increases lung fluid filtration in preterm lambs. Pediatr Res 30:616-621

2. Stefano JL, Abbasi S, Pearlman SA, Spear ML, Esterly KL, Bhutani VK 1991 Closure of the ductus arteriosus with indomethacin in ventilated neonates with respiratory distress syndrome. Effects of pulmonary compliance and ventilation. Am Rev Respir Dis 143:236-239

3. Szymankiewicz M, Hodgman JE, Siassi B, Gadzinowski J 2004 Mechanics of breathing after surgical ligation of patent ductus arteriosus in newborns with respiratory distress syndrome. Biol Neonate 85:32-36

4. Barlow AJ, Ward C, Webber SA, Sinclair BG, Potts JE, Sandor GG 2004 Myocardial contractility in premature neonates with and without patent ductus arteriosus. Pediatr Cardiol 25:102-107

5. Gerhardt T, Bancalari E 1980 Lung compliance in newborns with patent ductus arteriosus before and after surgical ligation. Biol Neonate 38:96-105

6. Naulty CM, Horn S, Conry J, Avery GB 1978 Improved lung compliance after ligation of patent ductus arteriosus in hyaline membrane disease. J Pediatr 93:682684

7. Yeh TF, Thalji A, Luken L, Lilien L, Carr I, Pildes RS 1981 Improved lung compliance following indomethacin therapy in premature infants with persistent ductus arteriosus. Chest 80:698-700

8. Cotton RB, Stahlman MT, Berder HW, Graham TP, Catterton WZ, Kover I 1978 Randomized trial of early closure of symptomatic patent ductus arteriosus in small preterm infants. J Pediatr 93:647-651

9. McCurnin D, Seidner S, Chang LY, Waleh N, Ikegami M, Petershack J, Yoder B, Giavedoni L, Albertine KH, Dahl MJ, Wang ZM, Clyman RI 2008 Ibuprofeninduced patent ductus arteriosus closure: physiologic, histologic, and biochemical effects on the premature lung. Pediatrics 121:945-956

10. Clyman RI, Chorne N 2007 Patent ductus arteriosus: evidence for and against treatment. J Pediatr 150:216-219

11. Kääpä P, Lanning P, Koivisto M 1983 Early closure of patent ductus arteriosus with indomethacin in preterm infants with idiopathic respiratory distress syndrome. Acta Paediatr Scand 72:179-184

12. Bose CL, Laughon MM 2007 Patent ductus arteriosus: lack of evidence for common treatments. Arch Dis Child Fetal Neonatal Ed 92:F498-F502

13. Chang LY, McCurnin D, Yoder B, Shaul PW, Clyman RI 2008 Ductus arteriosus ligation and alveolar growth in preterm baboons with a patent ductus arteriosus. Pediatr Res 63:299-302

14. Cassady G, Crouse DT, Kirklin JW, Strange MJ, Jonier CH, Godoy G, Odrezin GT, Cutter GR, Kirklin JK, Pacifico AD, Collins MV, Lell WA, Satterwhite C, Philips JB 1989 A randomized, controlled trial of very early prophylactic ligation of the ductus arteriosus in babies who weighed $1000 \mathrm{~g}$ or less at birth. N Engl J Med 320:15111516

15. Kabra NS, Schmidt B, Roberts RS, Doyle LW, Papile L, Fanaroff A 2007 Neurosensory impairment after surgical closure of patent ductus arteriosus in extremely low birth weight infants: results from the trial of indomethacin prophylaxis in preterms. J Pediatr 150:229-234

16. Chorne N, Leonard C, Piecuch R, Clyman RI 2007 Patent ductus arteriosus and its treatment as risk factors for neonatal and neurodevelopmental morbidity. Pediatrics 119:1165-1174

17. Clyman R, Cassady G, Kirklin JK, Collins M, Philips JB 2009 The role of patent ductus arteriosus ligation in bronchopulmonary dysplasia: reexamining a randomized controlled trial. J Pediatr 154:873-876

18. Moin F, Kennedy KA, Moya FR 2003 Risk factors predicting vasopressor use after patent ductus arteriosus ligation. Am J Perinatol 20:313-320

19. Roclawski M, Sabiniewicz R, Potaz P, Smoczynski A, Pankowski R, Mazurek T, Daibo B 2009 Scoliosis in patients with aortic coarctation and patent ductus arteriosus: does standard posterolateral thoracotomy play a role in the development of the lateral curve of the spine? Pediatr Cardiol 30:941-945

20. Smith ME, King JD, Elsherif A, Muntz HR, Park AH, Kouretas PC 2009 Should all newborns who undergo patent ductus arteriosus ligation be examined for vocal fold mobility? Laryngoscope 119:1606-1609

21. Clement WA, El-Hakim H, Phillipos EZ, Cote JJ 2008 Unilateral vocal cord paralysis following patent ductus arteriosus ligation in extremely low-birth-weight infants. Arch Otolaryngol Head Neck Surg 134:28-33

22. Gersony WM, Peckham GJ, Ellison RC, Miettinen OS, Nadas AS 1983 Effects of indomethacin in premature infants with patent ductus arteriosus: results of a national collaborative study. J Pediatr 102:895-906

23. Jhaveri N, Moon-Grady A, Clyman RI 2010 Early surgical ligation versus a conservative approach for management of patent ductus arteriosus that fails to close after indomethacin treatment. J Pediatr 157:381-387

24. Clyman RI, Chan CY, Mauray F, Chen YQ, Cox W, Seidner SR, Lord EM, Weiss H, Wale N, Evan SM, Koch CJ 1999 Permanent anatomic closure of the ductus arteriosus in newborn baboons: the roles of postnatal constriction, hypoxia, and gestation. Pediatr Res 45:19-29

25. Coalson JJ, Winter VT, Siler-Khodr T, Yoder BA 1999 Neonatal chronic lung disease in extremely immature baboons. Am J Respir Crit Care Med 160:1333-1346
26. Yoder BA, Siler-Khodr T, Winter VT, Coalson JJ 2000 High-frequency oscillatory ventilation: effects on lung function, mechanics, and airway cytokines in the immature baboon model for neonatal chronic lung disease. Am J Respir Crit Care Med 162:1867-1876

27. McCurnin DC, Yoder BA, Coalson J, Grubb P, Kerecman J, Kupferschmid J, Breuer C, Siler-Khodr T, Shaul PW, Clyman R 2005 Effect of ductus ligation on cardiopulmonary function in premature baboons. Am J Respir Crit Care Med 172:15691574

28. Naik AS, Kallapur SG, Bachurski CJ, Jobe AH, Michna J, Kramer BW, Ikegami M 2001 Effects of ventilation with different positive end-expiratory pressures on cytokine expression in the preterm lamb lung. Am J Respir Crit Care Med 164:494498

29. Speer CP 2006 Inflammation and bronchopulmonary dysplasia: a continuing story Semin Fetal Neonatal Med 11:354-362

30. Vozzelli MA, Mason SN, Whorton MH, Auten RL Jr 2004 Antimacrophage chemokine treatment prevents neutrophil and macrophage influx in hyperoxiaexposed newborn rat lung. Am J Physiol Lung Cell Mol Physiol 286:L488-L493

31. Kotecha S, Wilson L, Wangoo A, Silverman M, Shaw RJ 1996 Increase in interleukin (IL)-1 beta and IL-6 in bronchoalveolar lavage fluid obtained from infants with chronic lung disease of prematurity. Pediatr Res 40:250-256

32. Tullus K, Noack GW, Burman LG, Nilsson R, Wretlind B, Brauner A 1996 Elevated cytokine levels in tracheobronchial aspirate fluids from ventilator treated neonates with bronchopulmonary dysplasia. Eur J Pediatr 155:112-116

33. Groneck P, Gotze-Speer B, Oppermann M, Eiffert H, Speer CP 1994 Association of pulmonary inflammation and increased microvascular permeability during the development of bronchopulmonary dysplasia: a sequential analysis of inflammatory mediators in respiratory fluids of high-risk preterm neonates. Pediatrics 93:712-718

34. Ikegami M, Jobe AH 2002 Postnatal lung inflammation increased by ventilation of preterm lambs exposed antenatally to Escherichia coli endotoxin. Pediatr Res 52:356-362

35. Jobe AH, Kramer BW, Moss TJ, Newnham JP, Ikegami M 2002 Decreased indicators of lung injury with continuous positive expiratory pressure in preterm lambs. Pediatr Res 52:387-392

36. Seidner SR, Chen Y-Q, Oprysko PR, Mauray F, Tse MM, Lin E, Koch C, Clyman RI 2001 Combined prostaglandin and nitric oxide inhibition produces anatomic remodeling and closure of the ductus arteriosus in the premature newborn baboon. Pediatr Res 50:365-373

37. Yoder B, Martin H, McCurnin DC, Coalson JJ 2002 Impaired urinary cortisol excretion and early cardiopulmonary dysfunction in immature baboons. Pediatr Res 51:426-432

38. Bouayad A, Kajino H, Waleh N, Fouron JC, Andelfinger G, Varma DR, Skoll A, Vazquez A, Gobeil F Jr, Clyman RI, Chemtob S 2001 Characterization of PGE2 receptors in fetal and newborn lamb ductus arteriosus. Am J Physiol Heart Circ Physiol 280:H2342-H2349

39. Waleh N, Kajino H, Marrache AM, Ginzinger D, Roman C, Seidner SR, Moss TJ, Fouron JC, Vazquez-Tello A, Chemtob S, Clyman RI 2004 Prostaglandin E2mediated relaxation of the ductus arteriosus: effects of gestational age on g proteincoupled receptor expression, signaling, and vasomotor control. Circulation 110:2326-2332

40. Bhatt AJ, Pryhuber GS, Huyck H, Watkins RH, Metlay LA, Maniscalco WM 2001 Disrupted pulmonary vasculature and decreased vascular endothelial growth factor, Flt-1, and TIE-2 in human infants dying with bronchopulmonary dysplasia. Am J Respir Crit Care Med 164:1971-1980

41. Thomson MA, Yoder BA, Winter VT, Giavedoni L, Chang LY, Coalson JJ 2006 Delayed extubation to nasal continuous positive airway pressure in the immature baboon model of bronchopulmonary dysplasia: lung clinical and pathological findings. Pediatrics 118:2038-2050

42. McCurnin DC, Pierce RA, Willis BC, Chang LY, Yoder BA, Yuhanna IS, Ballard PL, Clyman RI, Waleh N, Maniscalco W, Crapo JD, Grubb PH, Shaul PW 2009 Postnatal estradiol up-regulates lung nitric oxide synthases and improves lung function in bronchopulmonary dysplasia. Am J Respir Crit Care Med 179:492-500

43. Pierce RA, Joyce B, Officer S, Heintz C, Moore C, McCurnin D, Johnston C, Maniscalco W 2007 Retinoids increase lung elastin expression but fail to alter morphology or angiogenesis genes in premature ventilated baboons. Pediatr Res 61:703-709

44. Maniscalco WM, Watkins RH, Pryhuber GS, Bhatt A, Shea C, Huyck H 2002 Angiogenic factors and alveolar vasculature: development and alterations by injury in very premature baboons. Am J Physiol Lung Cell Mol Physiol 282:L811-L823

45. Thébaud B, Abman SH 2007 Bronchopulmonary dysplasia: where have all the vessels gone? Roles of angiogenic growth factors in chronic lung disease. Am J Respir Crit Care Med 175:978-985

46. Jain RK 2003 Molecular regulation of vessel maturation. Nat Med 9:685-693

47. Hummler E, Barker P, Gatzy J, Beermann F, Verdumo C, Schmidt A, Boucher R, Rossier BC 1996 Early death due to defective neonatal lung liquid clearance in alpha-ENaC-deficient mice. Nat Genet 12:325-328

48. Noori S, Friedlich P, Seri I, Wong P 2007 Changes in myocardial function and hemodynamics after ligation of the ductus arteriosus in preterm infants. J Pediatr 150:597-602 